\title{
A glacier inventory for South Tyrol, Italy, based on airborne laser-scanner data
}

\author{
Christoph KNOLL, Hanns KERSCHNER \\ Institute of Geography, University of Innsbruck, Innrain 52, A-6020 Innsbruck, Austria \\ E-mail: christoph.knoll@uibk.ac.at
}

\begin{abstract}
A new approach to glacier inventory, based on airborne laser-scanner data, has been applied to South Tyrol, Italy: it yields highly accurate results with a minimum of human supervision. Earlier inventories, from 1983 and 1997, are used to compare changes in area, volume and equilibriumline altitude. A reduction of $32 \%$ was observed in glacier area from 1983 to 2006 . Volume change, derived from the 1997 and 2006 digital elevation models, was $-1.037 \mathrm{~km}^{3}$, and an ELA rise of $54 \mathrm{~m}$, to almost $3000 \mathrm{~m}$ a.s.l., was calculated for this period. Losses vary widely for individual glaciers, but have accelerated for all South Tyrolean glaciers since the first inventory in 1983.
\end{abstract}

\section{INTRODUCTION}

Glaciers have attracted increasing scientific and public interest as indicators of climate change within the last decade. In many countries, they also play an important economic role (e.g. for tourism (glacier-skiing resorts, mountaineering), for agriculture (irrigation) and for the production of hydropower). Guidelines for compiling a world glacier inventory (WGI), to assess their extent and volume, were published in the 1970s (UNESCO/IASH, 1970; Müller and others, 1977). The first Austrian inventory, based on data from 1969, was published by Patzelt (1978, 1980) and Gross (1987). The first Italian inventory was completed in 1983, following an earlier inventory by the Consiglio Nazionale delle Ricerche (e.g. CNR, 1962). Analysis of glacier-length changes worldwide (Hoelzle and others, 2003; Oerlemans, 2005), and recently for the Italian Alps (Citterio and others, 2007), provides valuable insights into glacier evolution during the past century.

National inventories have been compiled for Austria, based on aerial photos (Lambrecht and Kuhn, 2007), and for Switzerland, based on Landsat Thematic Mapper satellite imagery (Maisch and others, 2000; Kääb and others, 2002; Paul and others, 2004, 2007; Hoelzle and others, 2007). For South Tyrol, Italy, there are three different glacier inventories: the first, for 1983, was integrated into the WGI database as a table; the second, for 1997, was compiled from aerial photographs; while the most recent inventory, for 2006, is based on airborne laser-scanner (ALS) data and digital orthophotos.

During the last decade, ALS has become one of the standard methods for acquiring topographic data for a variety of applications (Arnold and others, 2006). The method is characterized by a high degree of automation, in terms of data acquisition and computer-aided analysis, in open-source software (e.g. with GRASS GIS (Geographic Resources Analysis Support System), or Windows-based software such as ArcGIS) (Geist and Stötter, 2003). Its use is now quite common in glaciology, but still has limitations (Kennett and Eiken, 1997; Favey and others, 1999; Geist and Stötter, 2003; Lutz and others, 2003; Hopkinson and Demuth, 2006; Kodde and others, 2007). Laser-profiling techniques have been applied in Greenland (Garvin and Williams, 1993; Bindschadler and others, 1999; Abdalati and others, 2002; Krabill and others, 2002) and in Alaska, Canada and the Canadian Arctic (Echelmeyer and others,
1996; Aðalgeirsdóttir and others, 1998; Sapiano and others, 1998; Abdalati and others, 2004; Schiefer and others, 2008). In Europe, various attempts have been made to utilize ALS for glaciological purposes (Baltsavias and others, 2001; Favey and others, 2002; Geist and Stötter, 2003, 2007; Lutz and others, 2003; Sithole and Vosselman, 2004; Würländer and others, 2004; Geist and others, 2005; Lippert and others 2006; Höfle and others, 2007).

ALS is a useful and powerful tool that facilitates the compilation of recent and historical glacier topographies, enabling the spatial extent of glaciers to be monitored semiautomatically with its raster data which can be classified into 'glacier' and 'non-glacier' area classes (Kodde and others, 2007). The single parameters used to derive glacier topographies are topographical smoothness, connectivity, hydrological constraints as well as slope, aspect and the size of individual glaciers. The outlines were calculated from ALS data using Kodde and others' (2007) delineation algorithm. The necessary data were acquired for the whole area of the Autonomous Province of Bolzano, South Tyrol, Italy, in 2005.

\section{DATA ACQUISITION AND DATA PROCESSING}

All glaciers in South Tyrol (Fig. 1) were included in the topographic survey used to compile the ALS digital elevation model (DEM), which satisfied the requirement that all the glaciers be captured at the end of the 2005 ablation season. By verifying outlines from the delineation algorithm on orthophotos from 2006, three glaciers previously unaccounted for were found in the Ortler-Cevedale group, resulting in a total glacier cover for South Tyrol of $94.1 \mathrm{~km}^{2}$ for 2006. The South Tyrolean glaciers are in high mountain regions, creating certain problems for the application of ALS. The rugged topography, with large differences in relief, can limit laser range, point density and spectral resolution (Lutz and others, 2003; Albertz, 2007), but this problem was overcome using state-of-the-art scanning equipment and by verifying the resulting glacier outlines on the 2006 digital orthophotos. This study comprises the entire glacierized area.

\section{ALS-based digital elevation model}

ALS data for the whole South Tyrolean territory (Fig. 1) were obtained by the Compagnia Generale Ripreseaeree (CGR), of Parma, under contract from the Autonomous Province of 


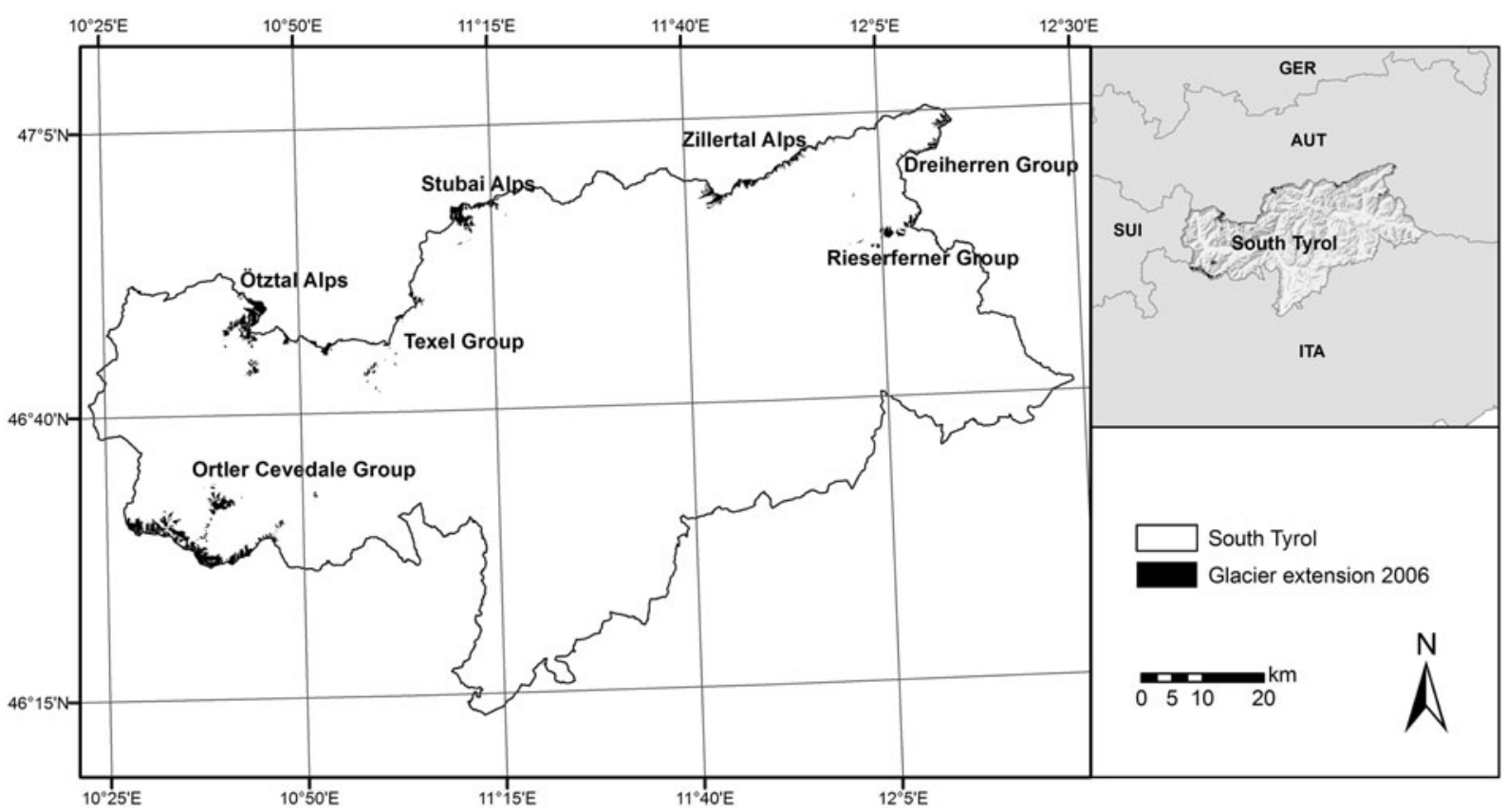

Fig. 1. South Tyrol and the ice-covered area in 2006, including the names of the mountain ranges.

Bozen, South Tyrol. The initial ALS point dataset was acquired using 'Optech ALTM 3033' and 'TopoSys Falcon II' scanner systems during late summer 2005. Specifications and recording accuracies of the two scanner systems used are shown in Table 1. Basic information on the ALS data acquisition was recorded during the flight with an integrated global positioning system (GPS) and an inertial measurement unit (IMU). The flight took place at the end of summer 2005 ; it provided an elevation accuracy of $\pm 0.4 \mathrm{~m}$ below $2000 \mathrm{~m}$ a.s.l. and $\pm 0.55 \mathrm{~m}$ above $2000 \mathrm{~m}$ a.s.l., giving sufficient accuracy for further calculations. An average point density of 8 points per $25 \mathrm{~m}^{2}$ was achieved for areas below $2000 \mathrm{~m}$ a.s.l., and 3 points per $25 \mathrm{~m}^{2}$ for areas above $2000 \mathrm{~m}$ a.s.l. The vertical accuracy over a control area was $0.095 \mathrm{~m}$ (G. Zanvettor and others, http://www.provinz.bz.it/ raumordnung/download/Beschreibg_Kartogr_2006.pdf). Full information on the collected data, i.e. first pulse, last pulse and intensity, is stored in a separate dataset that has not been released.

The ALS DEM was calculated from ALS point data (Wack and Stelzl, 2005); it has a $2.5 \mathrm{~m}$ raster resolution. The raster data form the input for the updated algorithms presented below (Kodde and others, 2007). As no orthophotos were available for the recording year of the DEM, those from 2006 were used to correct the glacier outlines.

\section{Orthophotos}

The CGR carried out survey flights during the summer of 2006 to obtain digital aerial photographs of the entire South Tyrolean area using the airborne digital sensor LH Systems ADS40. The resulting orthophotos were compiled at a scale of $1: 10000$ from scanning strips with a one-pixel ground resolution (pixel length $=0.5 \mathrm{~m}$ ). All photographs were taken in natural colour with a charge-coupled device (CCD) digital camera. The planimetric accuracy, as stated by the company, is $\pm 2 \mathrm{~m}$ for elevations below $2000 \mathrm{~m}$ a.s.l. and $\pm 6 \mathrm{~m}$ above $2000 \mathrm{~m}$ a.s.l. Basic information for these flights was also recorded with a GPS and an IMU. The georeferencing is based on a DEM with $40 \mathrm{~m}$ raster resolution.

\section{Calculation of glacier outlines}

The southern Stubai Mountains, in the north of South Tyrol, were chosen for testing the original delineation algorithm by Kodde and others (2007) for calculating glacier outlines based on the ALS DEM. Several different types of glacier (e.g. valley, mountain and glacierets) can be found there. Individual glaciers were delineated on the basis of smoothness, connectivity and hydrology. In the original delineation rule described in Kodde (2006), the laser intensity map was used as well. After checking the resulting delineations (Fig. 2), some improvements were made in the operation of this calculation rule, as the original method was developed for a completely different dataset based on different raster resolutions.

Improvement to Kodde's algorithm is based on: a thorough testing of several different raster datasets as input data $(1,2.5$ and $5 \mathrm{~m}$ raster resolution); the effects of the different raster resolutions; adaptation of default values (threshold and window size) to the $2.5 \mathrm{~m}$ ALS raster DEM or even bigger; enlargement of the script for calculating all possible glaciers, not just the largest one; and setting of the

Table 1. Area changes for all mountain ranges, 1983-2006

TopoSys Falcon II

Optech ALTM 3033

$\begin{array}{lc}\text { Range } & 300-1600 \mathrm{~m} \\ \text { Elevation accuracy } & \begin{array}{c}3-30 \mathrm{~cm} \text { depending on } \\ \text { satellite constellation }\end{array} \\ \text { Laser pulse rate } & 83 \mathrm{kHz} \\ \text { Scan rate } & 653 \mathrm{kHz} \\ \text { Laser wavelength } & 1560 \mathrm{~nm} \\ \text { Data recording } & \text { First echo, last echo } \\ & \text { and intensity }\end{array}$

265-3000m

$15 \mathrm{~cm}<1200 \mathrm{~m}$

$25 \mathrm{~cm}<2000 \mathrm{~m}$

$35 \mathrm{~cm}<3000 \mathrm{~m}$

$33 \mathrm{kHz}$

Varies with scan angle $1064 \mathrm{~nm}$

Simultaneous measurement in range of first and last pulse for each pulse emitted (DUAL TIM) 
Table 2. Specification and recording accuracies of the scanner systems used

\begin{tabular}{lrrr}
\hline Mountain range & $\begin{array}{c}\text { Area 1983 } \\
\mathrm{km}^{2}\end{array}$ & $\begin{array}{c}\text { Area 1997 } \\
\mathrm{km}^{2}\end{array}$ & $\begin{array}{c}\text { Area 2006 } \\
\mathrm{km}^{2}\end{array}$ \\
\hline Dreiherren Group & 6.56 & 5.19 & 4.18 \\
Ötztal Alps & 28.69 & 23.19 & 20.80 \\
Ortler-Cevedale Group & 49.85 & 41.63 & 37.45 \\
Rieserferner Group & 12.03 & 8.02 & 6.22 \\
Sesvenna Group & 0.17 & 0.08 & 0.00 \\
Stubai Alps & 14.76 & 11.95 & 10.43 \\
Texel Group & 8.56 & 4.99 & 3.53 \\
Zillertal Alps & 15.96 & 14.61 & 10.82 \\
\hline Total glacier area & & & \\
\hline
\end{tabular}

minimum glacier area to $1 \mathrm{ha}$. In a second step, the improved algorithm was used to identify all possible glaciers in South Tyrol. The main difference between the results of the two methods is that the accuracy for the new algorithm is limited by the raster size and resolution of the DEM, but this loss of accuracy could be corrected using digital orthophotos.

\section{Execution of the delineation algorithm}

The glacier delineations were determined with GRASS GIS. Initially, the raster datasets of the DEM were imported into the GRASS database, and the regions of the raster data were set for each raster tile to improve calculation speed.

The results of the improved algorithm are good, but not accurate enough for the mostly small South Tyrolean glaciers, $59.8 \%$ of which are smaller than $0.1 \mathrm{~km}^{2}$. The method also has limitations in the highly debris-covered ablation area of Suldenferner, Ortler-Cevedale Group. The identification of the slightly debris-covered parts of glaciers was done on the basis of the surface shape and roughness of the ALS DEM; for verification purposes orthophotos and a hillshade of the ALS DEM were used. For the extensively debris-covered tongue of Suldenferner, orthophotos from 2000, 2003 and 2006 were used to define the glacier tongue boundary. An estimation of the maximum error of the delineation algorithm in a sample of ten glaciers (two glaciers of each area class, analogous to Paul and others (2002)) resulted in an average maximum surface error of $\pm 3.7 \%$. Because of the small size of most of the South Tyrolean glaciers (mean of $0.39 \mathrm{~km}^{2}$ ), the results of the derivations were verified and corrected with the 2006 digital orthophotos. The corrected glacier boundaries were transformed to the ESRI polygon shapefile format, and ArcGIS was used to calculate additional information such as drainage area, identification number, glacier name, glacier area, aspect of the ablation area, etc. Once the glacier boundaries had been determined, additional information such as areaaltitude distributions, minimum, maximum and mean elevation of the glaciers was derived.

\section{Comparing different inventory datasets}

The data from the 1997 inventory are based on shapefiles for the glacier outlines and a DEM with a $20 \mathrm{~m}$ raster resolution from 1999 with a vertical accuracy of $\pm 5 \mathrm{~m}$, calculated from aerial photogrammetry data (G. Zanvettor and others, http:// www.provinz.bz.it/raumordnung/download/Beschreibg Kartogr_2006.pdf). The ALS-based DEM from 2005 has a

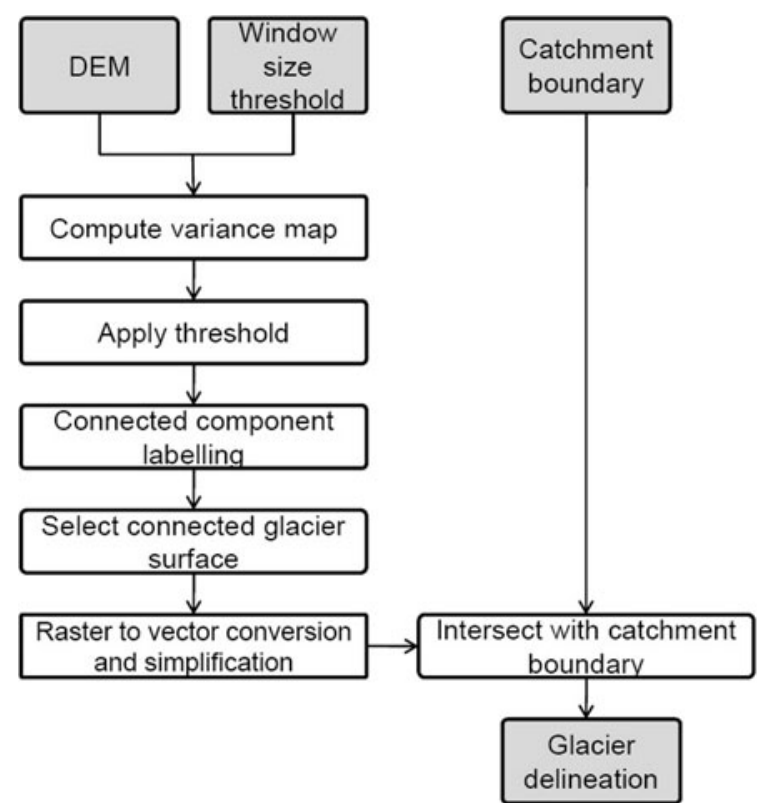

Fig. 2. Work of delineation algorithm (modified after Kodde and others, 2007).

resolution of $2.5 \mathrm{~m}$. In order to be able to compare the two different raster datasets, to assess the relative volume change, it was necessary to resample the $2.5 \mathrm{~m} 2005$ DEM with a bilinear interpolation to match the coarser $20 \mathrm{~m} 1999$ DEM. Subsequently, the resampled 2005 DEM was subtracted from the original $1999 \mathrm{DEM}$, resulting in a new raster with elevation changes. The extent of these changes depends on slope and aspect, as well as the flight direction of the ALS DEM (Kraus, 2005). A mean elevation difference of $5.7 \mathrm{~m}$ was calculated for all raster cells, both glacier and nonglacier, in the area of investigation. However, the most significant differences, attributable to inaccuracies in the 1999 DEM as well as in the 2005 DEM, occur in steep, rocky regions with a highly heterogeneous relief (Kraus, 2005). Such abrupt changes in elevation are negligible for the comparatively flat glacierized areas in South Tyrol.

\section{RESULTS}

\section{Changes in glacier area}

Three different inventories, from 1983, 1997 and 2006, have been analyzed. Results show a reduction in the glacierized area between 1983 and 2006 from $136.6 \mathrm{~km}^{2}$ to $93.4 \mathrm{~km}^{2}$ $(31.6 \%)$. From 1983 to 1997 the mean reduction was $19.7 \%$, and from 1997 to 2006 it was $11.9 \%$. The largest ice-covered region in South Tyrol is the Ortler-Cevedale Group, with a total glacier area of $37.5 \mathrm{~km}^{2}$ (2006). Within the investigated area, the area loss of $24.9 \%$ is the lowest for this region.

In general, mountain ranges with an extensive glacier cover in South Tyrol show different amounts of change (Table 2). The absolute area loss is greatest for the Ötztal Alps $\left(7.9 \mathrm{~km}^{2}\right)$ and the Ortler-Cevedale Group $\left(12.4 \mathrm{~km}^{2}\right)$. Between 1983 and 2006, 19 glaciers disappeared, but the number of glacier parts increased from 205 to 302. This phenomenon is due to the disintegration of individual glaciers, mostly in the Zillertal Alps (+37) and the OrtlerCevedale Group (+26). 


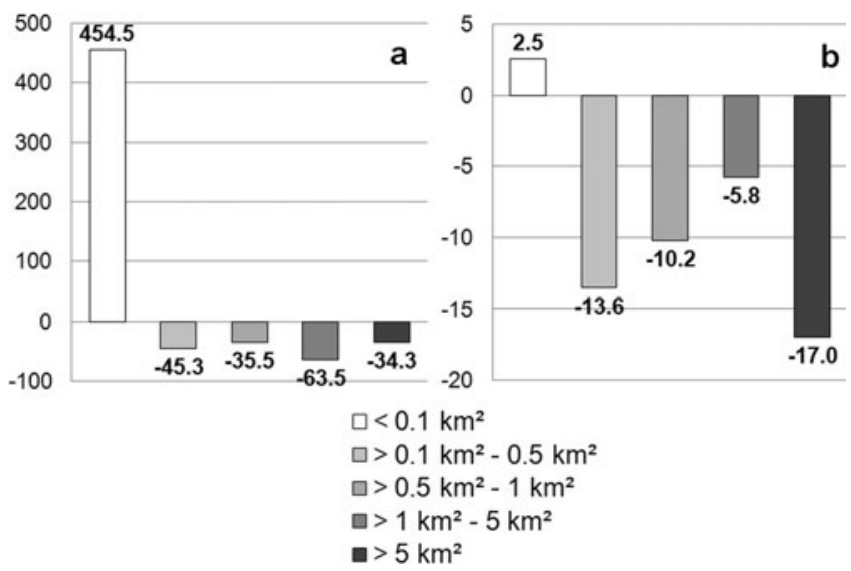

Fig. 3. Glacier number and area size change by different classes as (a) percentage change of the total number, and (b) total area $\left(\mathrm{km}^{2}\right)$ between 1983 and 2006 .

Figure 3a shows the relative shift of glaciers between area classes. In 2006 the number of glaciers $<0.1 \mathrm{~km}^{2}$ is 4.5 times higher than in 1983 and comprises $60 \%$ of the total glacier number, while the other area classes lost at least 34\% of their glaciers. Figure $3 \mathrm{~b}$ shows the loss of area in the corresponding area classes between the inventories of 1983 and 2006. The higher number of glaciers $<0.1 \mathrm{~km}^{2}$ demonstrates the impact of glacier disintegration in South Tyrol. Many glaciers $<0.5 \mathrm{~km}^{2}$ have melted and are now in the $<0.1 \mathrm{~km}^{2}$ class, accounting for the increased glacier area in this class.

\section{Changes in area-altitude distribution}

An analysis of the area-altitude distribution was only possible for the 1997 and 2006 inventories; no DEM or contour lines were available for the 1983 inventory. A comparison of the area-altitude distribution for both dates (Fig. 4) shows a maximum glacierized area of 30003100 ma.s.I. in 1997. In 2006, this maximum has shifted upwards by $100 \mathrm{~m}$ (one elevation band) to $3100-3200 \mathrm{~m}$ a.s.l. The largest change in glacier area, a loss of almost $8 \mathrm{~km}^{2}$, is observed between 2700 and $2900 \mathrm{ma.s.l}$. The slight increase in glacier area within the highest elevation band (3800 m a.s.l.) is a result of an extending firn cover on the plateau of Oberer Ortlerferner. In 1997, no firn remained up to the peaks of the highest mountains, but in 2006 firn and old snow survived at the highest elevations of the Ortler-Cevedale Group. The mean glacier elevation in 2006 was $3017 \mathrm{~m}$ a.s.l., meaning an upward shift of $39 \mathrm{~m}$ since 1997 (2978 ma.s.l.). This considerable change over 9 years underlines how the loss in area has affected almost all elevation bands, most of all at lower elevations.

\section{Volume changes}

The total change of ice and firn (volume change, $\Delta V$ ) in the glacierized area from 1997 to 2006 is $-1.037 \mathrm{~km}^{3}$ (Fig. 5). This $\Delta V$ is calculated from the difference between the two DEMs and is not corrected for the density of firn and glacier ice. The most extensively glacierized areas show the most volume loss. For example, in the Ortler-Cevedale Group almost $0.49 \mathrm{~km}^{3}$ of the ice and firn volume was lost (Table 3 ). Reductions in glacier volume show large variations, especially for small glaciers.

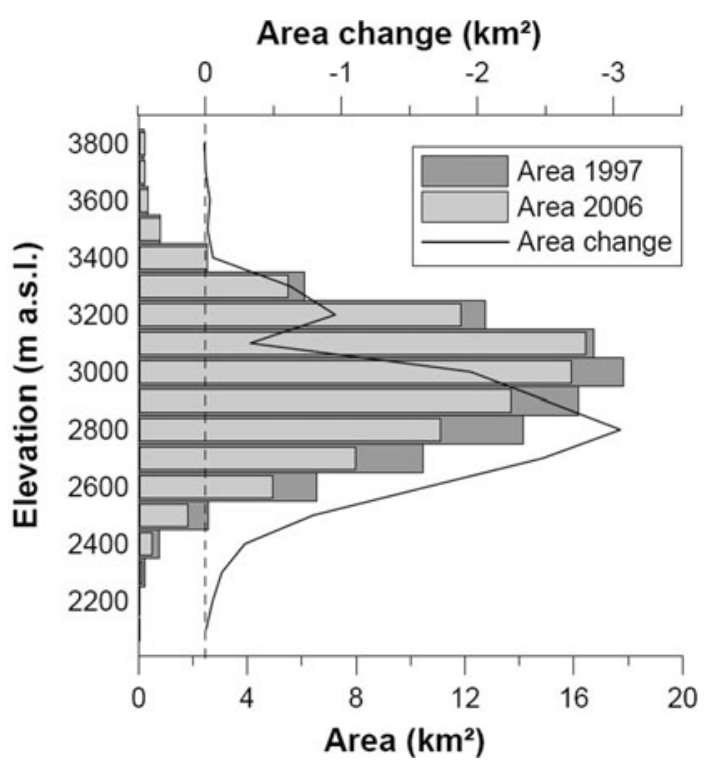

Fig. 4. Area-elevation distribution and area change by $100 \mathrm{~m}$ elevation bands between the two inventories.

A combination of area and volume changes during the last 9 years resulted in a mean elevation change of all glacierized areas of $-7.4 \mathrm{~m}$ (change in ice volume 19972006 divided by the 1997 glacier area). This corresponds very well with the results for the Austrian Ötztal Alps further to the north for the same period, where $-8.2 \mathrm{~m}$ of mean elevation change was observed (J. Abermann and others, http://www.phys.uu.nl/ boer0160/karthaus08/lecturenotes/ masschanges_oetztal_ja.pdf).

Major losses in area and volume are observed for valley glaciers like Suldenferner, Langtauferer Ferner (Ötztal Alps) and Übeltalferner (Stubai Alps), while small glaciers $\left(<1 \mathrm{~km}^{2}\right)$ show a large variation in losses, from a small expansion at high elevations to a complete downwasting, especially in lower ranges like the Rieserferner Group. Large valley glaciers show up to $-18.0 \mathrm{~m}$ in mean elevation change because their tongues reach very low areas with highly negative mass balances. Small glaciers are mostly situated at high altitudes, with a mean elevation of 3013 ma.s.l., and, with a few exceptions, cover only one to three elevation bands.

The elevation band with the highest absolute volume change lies $100 \mathrm{~m}$ above the elevation band with the highest absolute area change (2900-3000 ma.s.l.) and shows that very large areas are affected by net melting. More volume than area loss is observed, because of an increasing net melt rate at lower altitudes.

\section{Changes in ELA}

The equilibrium-line altitude (ELA) on glaciers is the altitude at which annual accumulation equals annual ablation. Changes in climatic conditions can be inferred from variations in the ELA (Kuhn, 1981; Ohmura and others, 1992; Lie and others, 2003). Gross and others (1977) suggested a steady-state accumulation-area ratio (AAR) of 0.67 for glaciers in the Alps for the approximation of the ELA. This approximation was used to derive the ELA here as well, despite the fact that glaciers were clearly not in a steady-state condition. Compared with measured ELAs on Langenferner and Weissbrunnferner based on mass-balance studies, the approximated ELA derived using the AAR 


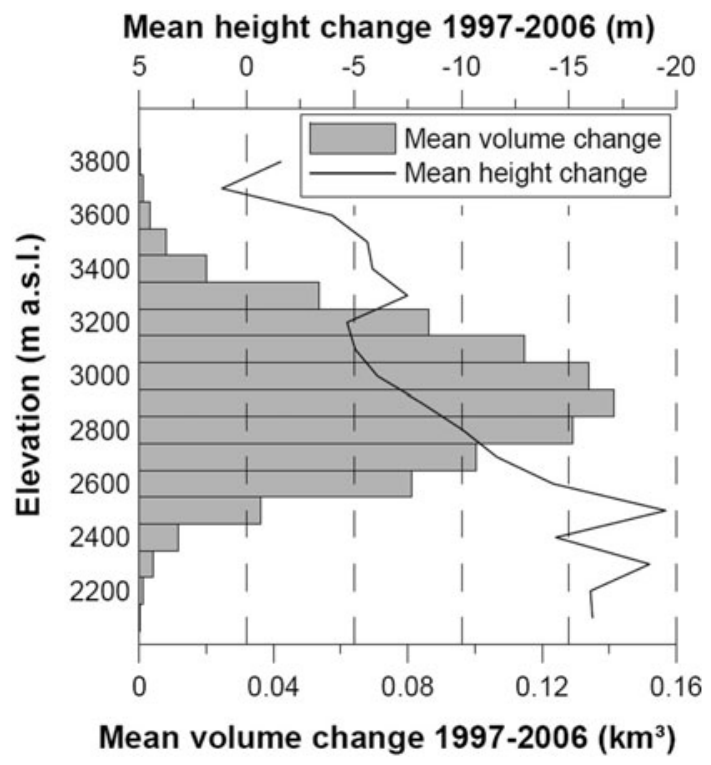

Fig. 5. Volume-loss-elevation distribution between the two inventories within $100 \mathrm{~m}$ elevation bands.

method was significantly lower (Di Lullo and others, 2008a,b). From 1997 to 2006 the calculated mean ELA for all mountain ranges in South Tyrol rose by $54 \mathrm{~m}$, from 2938 to $2992 \mathrm{~m}$ a.s.l., but there is large variability within the individual ranges. The most prominent rise of the mean ELA, $89 \mathrm{~m}$, occurred in the Ortler-Cevedale Group, while the mostly southerly-exposed Zillertal Alps show a rise of only 9 m (Fig. 6).

\section{CONCLUSIONS AND PERSPECTIVES}

Modern Earth-observation technologies (e.g. laser-scanning or radar remote sensing) enable glacier monitoring of extensive areas with both a high spatial and temporal resolution. The new South Tyrolean glacier inventory, based on ALS data, offered an opportunity to investigate glacier changes in areas with many small glaciers $\left(<0.1 \mathrm{~km}^{2}\right)$. It also provides a baseline for future studies of historical changes and of the development of the glacierized areas of the South Tyrolean Alps. Conclusions drawn from the two fully digital inventories of 1997 and 2006, and the table-based inventory

Table 3. Volume change for all mountain ranges between 1997 and 2006

\begin{tabular}{lc} 
Mountain range & $\begin{array}{c}\text { Volume change } \\
\mathrm{km}^{3}\end{array}$ \\
\hline Dreiherren Group & -0.043 \\
Ötztal Alps & -0.198 \\
Ortler-Cevedale Group & -0.491 \\
Rieserferner Group & -0.109 \\
Sesvenna Group & -0.001 \\
Stubai Alps & -0.072 \\
Texel Group & -0.046 \\
Zillertal Alps & -0.078 \\
\hline
\end{tabular}

Total volume change 1997/2006

$-1.038$

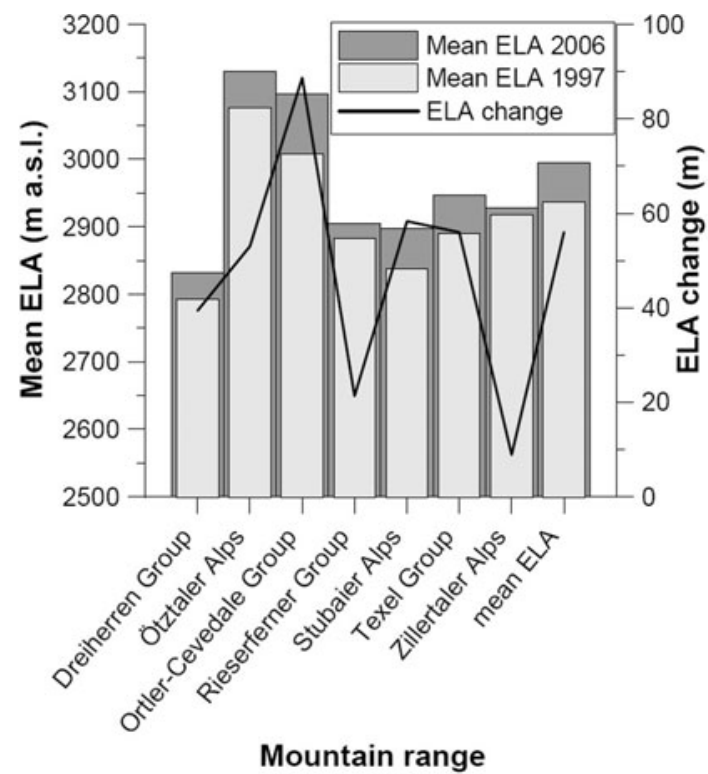

Fig. 6. ELA change between the two inventories of 1997 and 2006.

of 1983, correlate well with the 1996 Austrian glacier inventory (Lambrecht and Kuhn, 2007) and the 2000 Swiss glacier inventory (Maisch and others, 2000; Paul and others, 2002; Bauder and others, 2007). The 23 years between the 1983 and 2006 inventories have shown a strong decrease in the glacierized area and ice volumes for South Tyrol. Collapse and disintegration of many glaciers can be observed, especially in the Ortler-Cevedale Group and the Zillertal Alps, but there is also large spatial variability in the degree of loss between the individual mountain ranges. Strongly glacierized ranges, like the Ortler-Cevedale Group and the Ötztal Alps, are dominated by large glaciers $\left(>1 \mathrm{~km}^{2}\right)$ where area losses are below average, ranging from $24.9 \%$ to $27.5 \%$. The largest relative area losses occur in areas with little ice cover. The Sesvenna Group lost its only glacier, and there were extensive losses in the Texel Group (60\%). The loss of glacier area has affected almost all elevation bands; only the top band (3800 $\mathrm{m}$ a.s.l.) shows a slight increase. For all other ranges, losses appear to represent the reaction of glaciers to contemporary climatic conditions that have induced net ablation to the top of the highest peaks.

\section{ACKNOWLEDGEMENTS}

The present project is funded by a $\mathrm{PhD}$ scholarship at the University of Innsbruck. We thank M. Kodde for help in improving the glacier delineation algorithm, and G. Kaser, M. Kuhn and the Glaciological Seminar Innsbruck for their support. We also thank S. Ommanney (scientific editor), A. Arendt and an anonymous reviewer for helpful comments.

\section{REFERENCES}

Abdalati, W. and 9 others. 2002. Airborne laser altimetry mapping of the Greenland ice sheet: application to mass balance assessment. J. Geodyn., 34(3-4), 391-403.

Abdalati, W. and 9 others. 2004. Elevation changes of ice caps in the Canadian Arctic Archipelago. J. Geophys. Res., 109(F4), F04007. (10.1029/2003JF000045.) 
Aðalgeirsdóttir, G., K.A. Echelmeyer and W.D. Harrison. 1998. Elevation and volume changes on the Harding Icefield, Alaska. J. Glaciol., 44(148), 570-582.

Albertz, J. 2007. Einführung in die Fernerkundung. Grundlagen der Interpretation von Luft und Satellitenbildern. Third edition. Darmstadt, Wissenschaftliche Buchgesellschaft.

Arnold, N.S., W.G. Rees, B.J. Devereux and G.S. Amable. 2006. Evaluating the potential of high-resolution airborne LiDAR data in glaciology. Int. J. Remote Sens., 27(6), 1233-1251.

Baltsavias, E., E. Favey, A. Bauder, H. Bösch and M. Pateraki. 2001. Digital surface modelling by airborne laser scanning and digital photogrammetry for glacier monitoring. Photogramm. Rec., 17(98), 243-273.

Bauder, A., M. Funk and M. Huss. 2007. Ice-volume changes of selected glaciers in the Swiss Alps since the end of the 19th century. Ann. Glaciol., 46, 145-149.

Bindschadler, R.A., M. Fahnestock and A. Sigmund. 1999. Comparison of Greenland Ice Sheet topography measured by TOPSAR and airborne laser altimetry. IEEE Trans. Geosci. Remote Sens., 37(5), 2530-2535.

Citterio, M. and 6 others. 2007. The fluctuations of Italian glaciers during the last century: a contribution to knowledge about Alpine glacier changes. Geogr. Ann., 89(3), 167-184.

Consiglio Nazionale delle Ricerche (CNR). 1962. Catasto dei ghiacciai Italiani. Ghiacciai della Lombardia e dell'OrtlesCevedale. Vol. III. Torino, Consiglio Nazionale delle Ricerche. Comitato Glaciologico Italiano.

Di Lullo, A., R. Dinale, E. Mair, C. Oberschmied and D. Peterlin. 2008a. Ghiacciaio di Fontana Bianca - Weissbrunnferner anno idrologico 2006/2007 Haushaltsjahr. Supplemento a Climareport 150. Glacierreport Südtirol - Alto Adige, 01/ 2008. Bolzano, Ufficio Idrografico di Bolzano.

Di Lullo, A., R. Dinale, D. Peterlin, E. Mair and R. Prinz. 2008b. Vedretta Lunga - Langenferner - anno idrologico 2006/2007 Haushaltsjahr. Supplemento al Climareport 152. Glacierreport Südtirol - Alto Adige, 03/2008. Bolzano, Ufficio Idrografico di Bolzano.

Echelmeyer, K.A. and 8 others. 1996. Airborne surface profiling of glaciers: a case-study in Alaska. J. Glaciol., 42(142), $538-547$

Favey, E., A. Geiger, G.H. Gudmundsson and A. Wehr. 1999. Evaluating the potential of an airborne laser-scanning system for measuring volume changes of glaciers. Geogr. Ann., 81A(4), $555-561$.

Favey, E., A. Wehr, A. Geiger and H.-G. Kahle. 2002. Some examples of European activities in airborne laser techniques and an application in glaciology. J. Geodyn., 34(3-4), 347-355.

Garvin, J.B. and R.S. Williams, Jr. 1993. Geodetic airborne laser altimetry of Breiðamerkurjökull and Skeiðarárjökull, Iceland, and Jakobshavns Isbræ, West Greenland. Ann. Glaciol., 17, 379-385.

Geist, T. and J. Stötter. 2003. First results on airborne laser scanning technology as a tool for the quantification of glacier mass balance. EARSeL eProc., 2(1), 8-14.

Geist, T. and J. Stötter. 2007. Documentation of glacier surface elevation change with multi-temporal airborne laser scanner data - case study: Hintereisferner and Kesselwandferner, Tyrol, Austria. Z. Gletscherkd. Glazialgeol., 41, 77-106.

Geist, T., H. Elvehøy, M. Jackson and J. Stötter. 2005. Investigations on intra-annual elevation changes using multi-temporal airborne laser scanning data: case study Engabreen, Norway. Ann. Glaciol., 42, 195-201.

Gross, G. 1987. Der Flächenverlust der Gletscher in Österreich 1850-1920-1969. Z. Gletscherkd. Glazialgeol., 23(2), 131-141.

Gross, G., H. Kerschner and G. Patzelt. 1977. Methodische Untersuchungen über die Schneegrenze in alpinen Gletschergebieten. Z. Gletscherkd. Glazialgeol., 12(2), 223-251.

Hoelzle, M., W. Haeberli, M. Dischl and W. Peschke. 2003. Secular glacier mass balances derived from cumulative glacier length changes. Global Planet. Change, 36(4), 295-306.
Hoelzle, M., T. Chinn, D. Stumm, F. Paul, M. Zemp and W. Haeberli. 2007. The application of glacier inventory data for estimating past climate change effects on mountain glaciers: a comparison between the European Alps and the Southern Alps of New Zealand. Global Planet. Change, 56(1-2), 69-82.

Höfle, B., T. Geist, M. Rutzinger and N. Pfeifer. 2007. Glacier surface segmentation using airborne laser scanning point cloud and intensity data. Int. Arch. Photogramm. Remote Sens. Spatial Inform. Sci., 36(3/W52), 195-200.

Hopkinson, C. and M.N. Demuth. 2006. Using airborne lidar to assess the influence of glacier downwasting on water resources in the Canadian Rocky Mountains. Can. J. Remote Sens., 32(2), 212-222.

Kääb, A., F. Paul, M. Maisch, M. Hoelzle and W. Haeberli. 2002. The new remote-sensing-derived Swiss glacier inventory: II. First results. Ann. Glaciol., 34, 362-366.

Kennett, M. and T. Eiken. 1997. Airborne measurement of glacier surface elevation by scanning laser altimeter. Ann. Glaciol., 24, 293-296.

Kodde, M. 2006. Glacier surface analysis: airborne laser scanning for monitoring glaciers and crevasses. (MSc thesis, Delft University of Technology.)

Kodde, M., N. Pfeifer, B. Gorte, T. Geist and B. Höfle. 2007. Automatic glacier surface analysis from airborne laser scanning. Int. Arch. Photogramm. Remote Sens. Spatial Inform. Sci., 36(3/ W52), 221-226.

Krabill, W.B. and 8 others. 2002. Aircraft laser altimetry measurement of elevation changes of the Greenland ice sheet: technique and accuracy assessment. J. Geodyn., 34(3-4), 357-376.

Kraus, K. 2005. Laserscanning und Photogrammetrie im Dienste der Geoinformation. In Strobl, J., T. Blaschke and G. Griesebner, eds. AGIT Symposium 2005 - Angewandte Geoinformatik, 6-8 July 2005. Beiträge zum 17. Salzburg, Wichmann, 286-396.

Kuhn, M. 1981. Climate and glaciers. IAHS Publ. 131 (Symposium at Canberra 1979 - Sea Level, Ice and Climatic Change), 3-20.

Lambrecht, A. and M. Kuhn. 2007. Glacier changes in the Austrian Alps during the last three decades, derived from the new Austrian glacier inventory. Ann. Glaciol., 46, 177-184.

Lie, Ø., S.O. Dahl and A. Nesje. 2003. A theoretical approach to glacier equilibrium-line altitudes using meteorological data and glacier mass-balance records from southern Norway. Holocene, 13(3), 365-372.

Lippert, J., M. Wastl, J. Stötter, A.P. Moran, Th. Geist and C. Geitner. 2006. Measuring and modelling ablation and accumulation on glaciers in Northern Iceland. Z. Gletscherkd. Glazialgeol., 39, 87-98.

Lutz, E., T. Geist and J. Stötter. 2003. Investigations of airborne laser scanning signal intensity on glacial surfaces - utilizing comprehensive laser geometry modeling and orthophoto surface modeling (a case study: Svartisheibreen, Norway). Int. Arch. Photogramm. Remote Sens. Spatial Inform. Sci., 34(3/W13), 143-148.

Maisch, M., A. Wipf, B. Denneler, J. Battaglia and C. Benz. 2000. Die Gletscher der Schweizer Alpen. Gletscherhochstand 1850, Aktuelle Vergletscherung, Gletscherschwund-Szenarien. Zürich, vdf Hochschulverlag AG ETH. (Schlussbericht NFP 31.)

Müller, F., T. Caflisch and G. Müller. 1977. Instructions for the compilation and assemblage of data for a world glacier inventory. Zürich, ETH Zürich. Temporary Technical Secretariat for the World Glacier Inventory.

Oerlemans, J. 2005. Extracting a climate signal from 169 glacier records. Science, 308(5722), 675-677.

Ohmura, A., P. Kasser and M. Funk. 1992. Climate at the equilibrium line of glaciers. J. Glaciol., 38(130), 397-411.

Patzelt, G. 1978. Der Österreichische Gletscherkataster. In Almanach '78 der Österreichischen Forschung. Wien, Verband der wissenschaftlichen Gesellschaften Österreichs, 129-133.

Patzelt, G. 1980. The Austrian glacier inventory: status and first results. IAHS Publ. 126 (Workshop at Riederalp 1978 - World Glacier Inventory), 181-183. 
Paul, F., A. Kääb, M. Maisch, T. Kellenberger and W. Haeberli. 2002. The new remote-sensing-derived Swiss glacier inventory. I. Methods. Ann. Glaciol., 34, 355-361.

Paul, F., A. Kääb, M. Maisch, T. Kellenberger and W. Haeberli. 2004. Rapid disintegration of Alpine glaciers observed with satellite data. Geophys. Res. Lett., 31(21), L21402. (10.1029/ 2004GL020816.)

Paul, F., A. Kääb and W. Haeberli. 2007. Recent glacier changes in the Alps observed from satellite: consequences for future monitoring strategies. Global Planet. Change, 56(1-2), 111-122.

Sapiano, J.J., W.D. Harrison and K.A. Echelmeyer. 1998. Elevation, volume and terminus changes of nine glaciers in North America. J. Glaciol., 44(146), 119-135.

Schiefer, E., B. Menounos and R. Wheate. 2008. An inventory and morphometric analysis of British Columbia glaciers, Canada. J. Glaciol., 54(186), 551-560.
Sithole, G. and G. Vosselman. 2004. Experimental comparison of filter algorithms for bare-Earth extraction from airborne laser scanning point clouds. ISPRS J. Photogramm. Rem. Sens., 59(1-2), 85-101.

UNESCO/International Association of Scientific Hydrology (IASH). 1970. Perennial ice and snow masses: a guide for compilation and assemblage of data for a world inventory. Paris, UNESCO/ International Association of Scientific Hydrology. (Technical Papers in Hydrology 1, A2486.)

Wack, R. and H. Stelzl. 2005. Laser DTM generation for SouthTyrol and 3D-visualization. Int. Arch. Photogramm. Remote Sens. Spatial Inform. Sci., 36(3/W19), 48-53.

Würländer, R., K. Eder and T. Geist. 2004. High quality DEMs for glacier monitoring - image matching versus laser scanning. Int. Arch. Photogramm. Remote Sens., 35(B7), 753-758. 